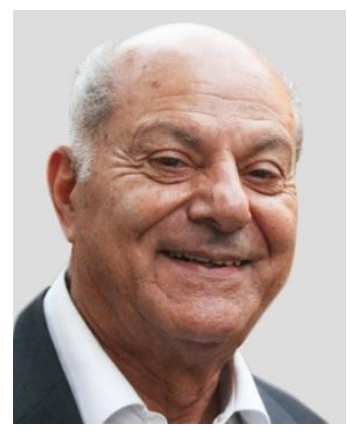

\title{
Future of Energy in Egypt and the World
}

\author{
Dr.-Eng. Hani Mahmoud El-Nokraschy
}

If the whole world, which Egypt is a part of, continues business as usual in the field of electricity generation, namely, using the same regimes adopts today, burning fossil fuels and Uranium fission, both fuels will run out within sixty years at most and the world will definitely return to the Stone Age. Shall this be the end of the Egyptian people ... the history makers?

Generating energy is the next necessity to human life after water and food, since it is the major stimulus of development. However, what is the aim of development if it is only momentary; then followed by an endless abyss?

Shall we wait till fossil and nuclear fuels run out? Jostling over the remaining fuel will certainly be fierce and we will pay a high price for it, a matter that will subsequently lead to demolishing the ingredients of development.

Considering that oil is now dominating our way of life, it shall be wise to start immediately planning for the post-oil age, provided that it is a sustainable plan set up to continue its validity as long as humans live on this planet; this cannot be achieved except if we shift to renewable energies.

Looking at Egypt and its available renewable energy sources, it becomes evident that the solar energy, particularly in Upper Egypt, can give more than the present and future needs of the Egyptian society and even cover the demand of the whole world for electricity.

However, success of any plan in this regard depends mainly on the appropriate techniques adopted to realize it. There are two techniques to utilize solar energy in order to generate electricity:

Firstly, solar cells that transform sun light directly to electricity. However, this technique does not allow storing - on a large scale - of the daily produced electricity to be used at night and therefore, there will be no electricity after sunset.

Secondly, mirror focusing of sunrays to obtain high temperature that makes it possible to heat water and generate high temperature and high-pressure steam, exactly like fossil-fueled boilers do in the majority of conventional power stations in the world. This technique is capable of storing a significant portion of the heat collected during the sunny hours to be used during night to produce electricity. This means that the Concentrating Solar Power (CSP) technique can replace fossil fuels completely, because thermal storage costs a hundredth of that of electricity storage. Egypt's qualitative advantage is the availability of direct sunrays, in contrast to northern countries having mainly diffuse sunrays; only direct sunrays can be bundled and thus concentrated on a focus, obviously the condition for utilizing this technique.

Therefore, solar thermal power stations equipped with storage will spare Egypt importing fuels to generate electricity as well as establishing nuclear plants since they are less in costs than nuclear plants of same capacity and reveal equal performance; moreover, decrease in costs when multiple units are put in operation. Another significant advantage is that they can be much more rapidly manufactured, commissioned and operated than conventional or nuclear power stations, giving them the ability to cope with the highly increasing demand on electricity. Besides, they do not produce dangerous wastes or emissions. Finally, most of their components can be manufactured locally thus providing job opportunities and encourage establishing of complementary industries.

For such power stations, standardizing a small capacity unit, offers better chances for financing and paves the way to mass production. Small units with air cooled condensers can be placed anywhere in the desert, thus giving flexibility in regards to selecting their location as no special site conditions are 
required as to be in vicinity of a water stream. Thus the power station can be placed near new residential complexes or along the south-north electricity line to inject power to it instead of reinforcing the line. This strategy decreases load over lines as well as electricity transfer losses; since selecting the location for the power station does not necessitate having a water stream. In case that the power station is located near the seashore, its waste heat can be used for desalting seawater resulting in very low cost drinking water because energy used for desalination is available as waste heat.

Following such a policy will definitely boost Egypt's rank in the countries exporting expertise and special equipment to establish such stations. Furthermore, Egypt possesses all the ingredients of development and atop of which are its intelligent persistent people and imperishable energy sources.

It is also worth mentioning that desalination of seawater is the only way out for Egypt to provide enough water and consequently food. Limitation of the River Nile water forces the farmers to reduce irrigation water thus reducing wash out of salts from the earth and consequently increasing land salinity that damages the land for years to come. Experience provides evidence for such dangerous exercises.

Let us have a glans at the civilization history of the Egyptian people. A civilization that extends for more than 7000 years, whereas during the last 5000 years the oldest state on earth was established, that still exists and glares with its donation. Looking that way raises a significant question: is our generation entitled to spoil the fertile land that we have inherited from our ancestors and on which we have lived in dignity and pride the last millenniums.

For all these reasons, we have proposed adopting a sustainability framework in the Egyptian Constitution:

Preserving the country's resources by applying sustainability principles in agriculture, energy production and other community requirements to guarantee the wellbeing of future generations

We are truly grateful to Almighty God that the Founding Committee of the Egyptian Constitution has responded to this proposal and required to adopt sustainability principles in at least six articles including article 32 stipulating that the government should abide by using renewable energies:

\section{"The State is committed to the optimum utilization of sources of renewable energy"}

Hereunder are some examples of solar thermal power stations using different schemes that have been successfully implemented and are commercially operating:

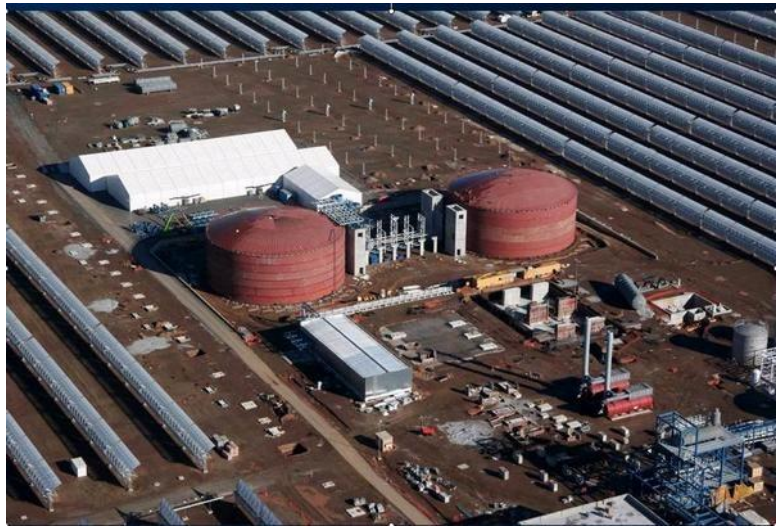

Rows of solar reflectors consisting of longitudinal parabolic mirrors (Parabolic troughs) in the $50 \mathrm{MW}$ solar power station in Spain "ANDASOL". It has thermal storage that allows it to operate for seven and a half hours after the sunset

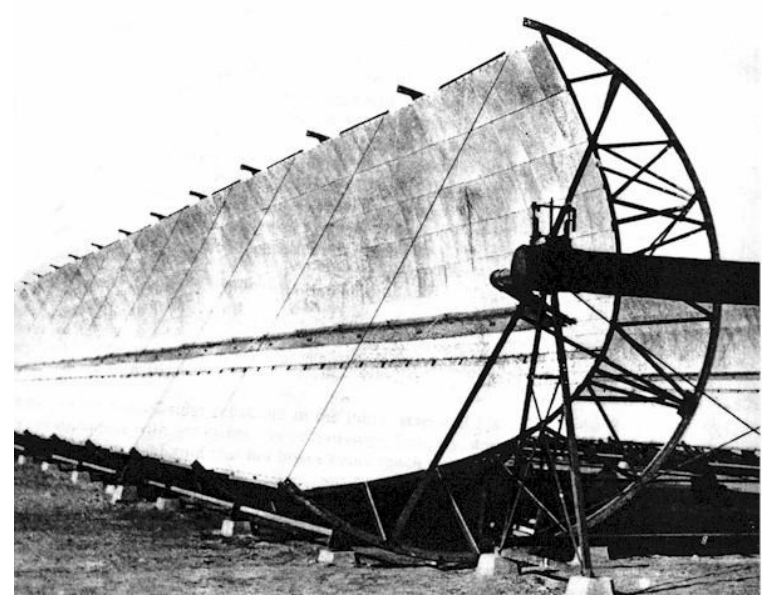

Longitudinal parabolic mirror (crescent shaped) This was the first commercial application of concentrating thermal solar power. Installed in Maady, near Cairo 1913 to produce steam for pumping the Nile water to the cotton fields 


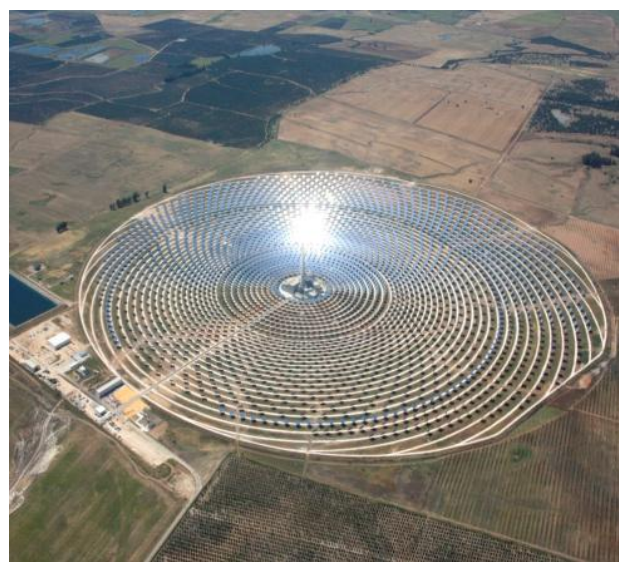

Solar Power Tower Technology, Gemasolar in Spain, 19.9 MW with 15 hours storage

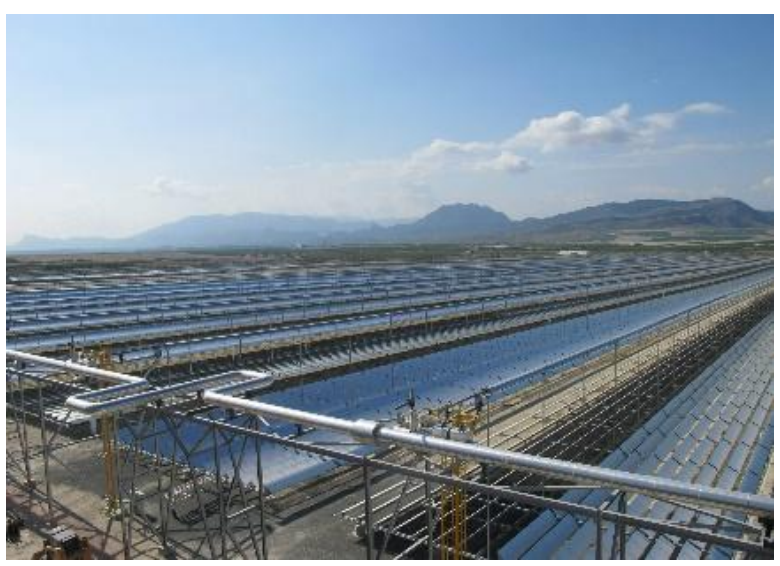

Fresnel Flat Mirror Technology, Puerto Errado in Spain, $30 \mathrm{MW}$ with 0.5 hours Storage

\section{About Dr.-Eng. Hani Mahmoud El-Nokraschy}

After graduating with a BSc. in Mechanical Engineering from the Faculty of Engineering, Cairo University in 1958, he pursued his graduate studies in Germany at the Technical University of Darmstadt where he received his Dipl.Ing. (MSc.) in 1963 and his Dr.-Ing. (PhD) in 1968.

Dr. El Nokraschy worked at the Transport and Engineering Company in Cairo from 1957 to 1958 .

After receiving his PhD in 1968 he joined SCHENCK in Darmstadt, Germany. He was appointed as Head of the Research Department for Vibrating Machines in 1983. He continued working at SCHENCK until he moved to MOGENSEN in Wedel, Germany in 1991, where he occupied the position of Head of Design and R\&D .

In 1998, he founded his own consultancy services, NOKRASCHY ENGINEERING GmbH in Germany, where he discovered the attractiveness of renewable energies, especially for his birth country Egypt which is blessed by excellent sun and wind conditions.

He participated as a team member at the German AeroSpace Center (DLR), from 2004 to 2007 to the research on renewable energies around the Mediterranean and deploying renewable energies for seawater desalination. In 2007, he also participated as a member of the renewable energy team at the German-Egyptian Year of Science and Technology .

In 2009, he was appointed by the Centre of Future Studies at the Information and Decision Support Centre (IDSC) of the Egyptian Cabinet to conduct a study on the future of electricity in Egypt. He suggested therein a gradual but definitive shift to renewable energies within this century.

Dr. El Nokraschy is a member of Advisory Board, and MSc. lecturer and examiner at REMENA joint program of Cairo University in collaboration with Kassel University, Germany .

He was one of the founders of the DESERTEC foundation in Jan. 2009 and vice Chairman of the Supervisory Board. His last position at the Foundation was Chairman of Board of Trustees till September 2014 when he was nominated as a member of the Scientific Advisory Council to the President of Egypt.

Further activities and positions :

- Founding member - 1996 - of the Egyptian Businessmen Association in Germany and Secretary General since 2013 .

- $\quad$ Member of the General Union of Egyptians Abroad (Cairo).

- Head of the Supervisory Board to the Supreme Council of Egyptian Associations in Germany .

- Member of the German Association of Scientists (VDW) since 2013. 


\title{
مستقبل الطاقة في مصر و العالم
}

\author{
د. ـمهندس هانئ محمود النقر اشي
}

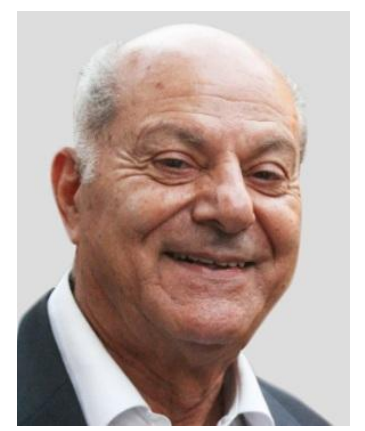

إذا استمر العالم - و مصر جزء منه ــ في إنتاج الكهرباء بالنمط الحالي، أي حرق الوقود الحفري و شطر اليور انيوم، فسينفد

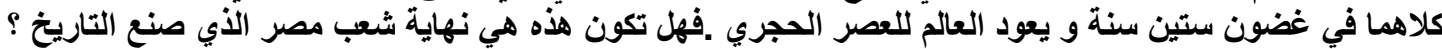

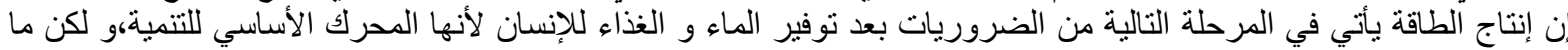

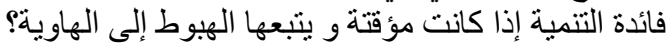

إذا انتظرنا إلى قرب نفاد كلا الوقود الحفري و الإنشطاري، سيكون التزاحم على شراء ما تبقى منه على أشده و لن نحصل عليه إلا بغالي الثمن الذي يقوض مقومات التنمية.

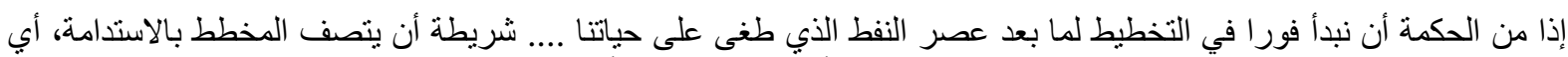

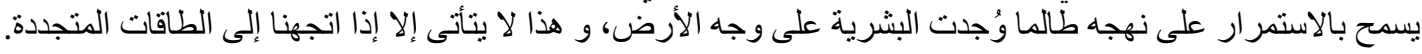

بنظرة إلى المتاح في مصر من الطاقات المتجددة المعروفة، نجد أن الطاقة الثمسية ـ و خاصة في صعيد مصر ـ أكثر من احتياجات المجتمع المصري الآن و في المستقبل، بل تكفي التلبية منطلبات العالم كله.

و لكن نجاح أي مخطط في هذا الصدد يعتمد في الدرجة الأولى على التقنية المناسبة لتحقيقه .و لاستخدام الطاقة الثمسية لإنتاج

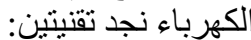

الخلايا الثمسية التي تحوّل ضوء الثئ الثمس إلى كهرباء مباثرة، و هذه لا تتيح تخزين الكهرباء المُنتجة نهار لاستخدامها ليلا، فلا

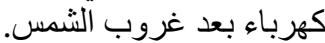

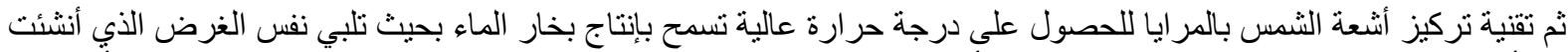

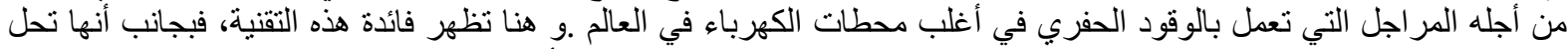

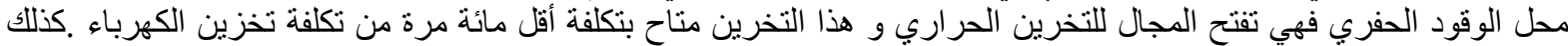

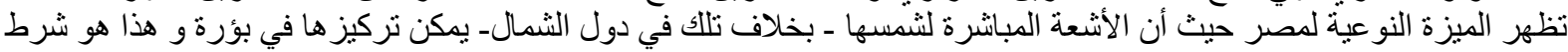
تفعيل هذه التقنية.

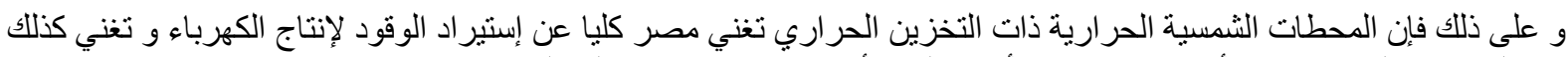

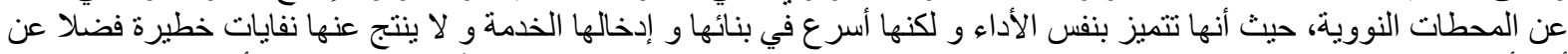

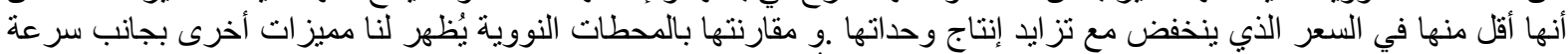

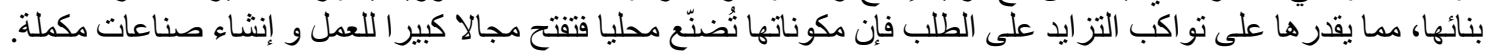

إختبار قدرة نمطية صغيرة للمحطة فيه يُسر للتمويل و يتيح إنتاجها بأعداد كبيرة .و اختيار موقعها قرب التجمعات السكنية و نشرها

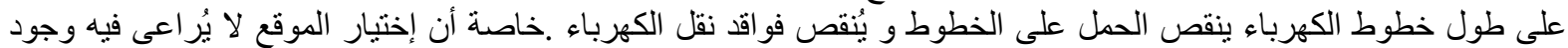

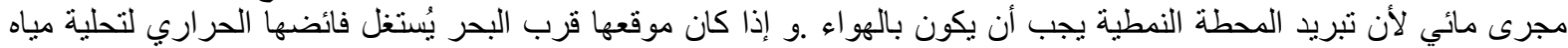
البحر ، فيكون الحصول على مياه الثرب بأقل التكاليف لعدم استخدامه طاقة إضافية.

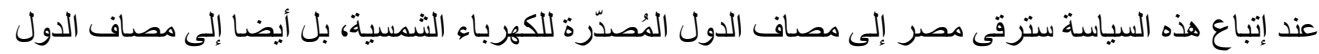

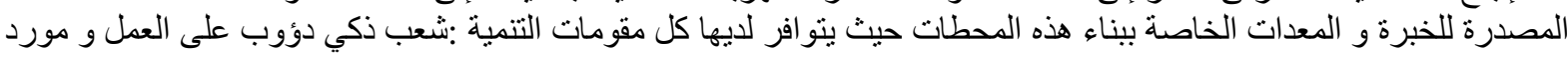

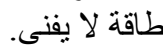

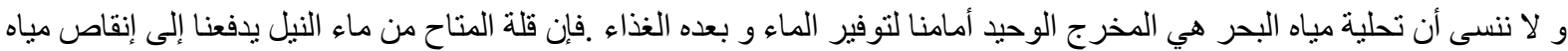

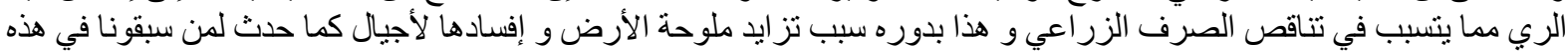


لختام هذا الحديث، إذا نظرنا إلى تاريخ شعب مصر الذي تمتد حضارته لأكثر من سبعة آلاف عام أرسى في الآلاف الخمس الأخيرة

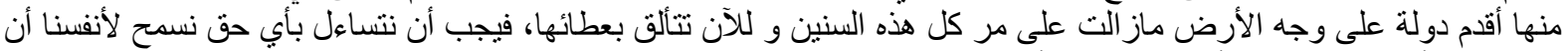
نفسد هذه الأرض الطيبة بعد أن ورثناها من أجدادنا في حالة صحية خصبة سمحت لنا بالعيش فيها بكر امة و عزة فئ.

$$
\text { لكل هذه الأسباب اقترحنا تثبيت إطار الإستدامة في دستور مصر : }
$$

الحفاظ على مقومات الدولة بتطبيق مبادئ الإستدامة في الزراعة و وإنتاج الطاقة

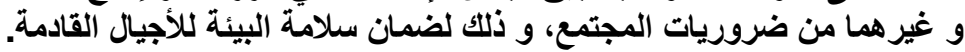

و نحمد الله عز و جل أن استجابت لجنة وضع الدستور لهذا الاقتر اح و ضمنت مبادئ الاستدامة في ستة مو اد على الأقل منها المادة 32 و التي تلزم الحكومة باستخدام الطاقات المتجددة:

"كما تلتزم الدولة بالعمل على الاستغلال الأمثل لمصادر الطاقة المتجددة" أمثلة عملية لمحطات شمسية بتقنيات مختلفة نُفذت بنجاح:

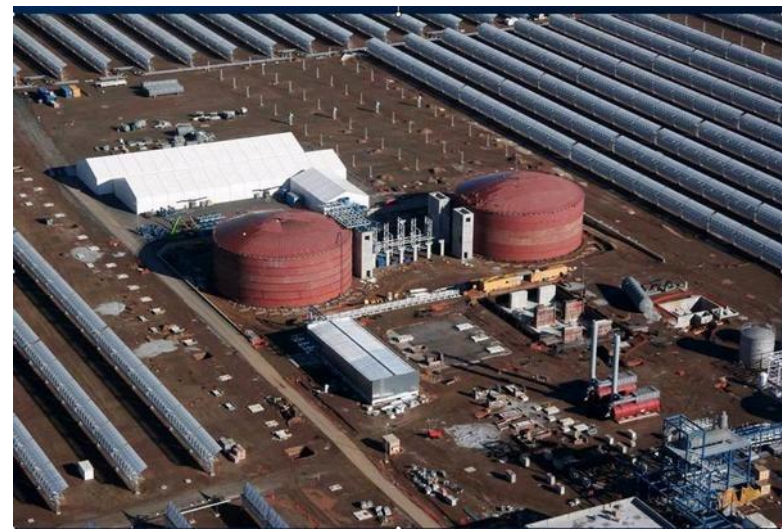

تقنية المرايا ذات القطع المكافئ

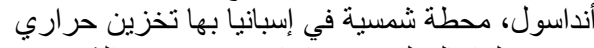

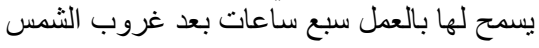

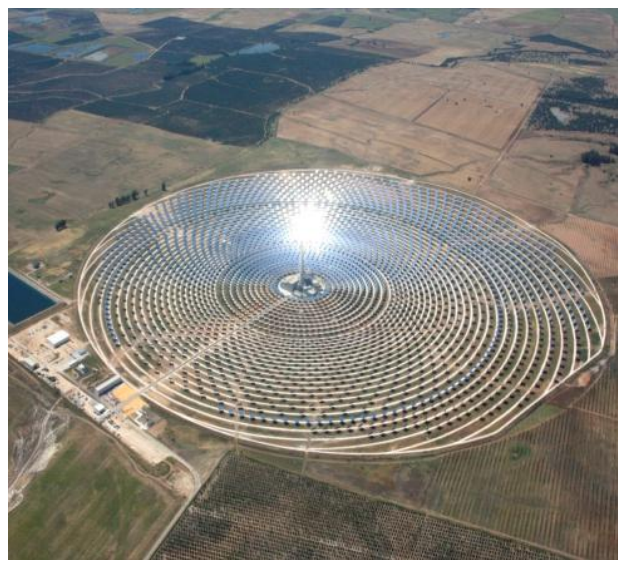

تقتية البرج الشمسي

جيماسو لار في إسبانيا تخزين 15 ساعة

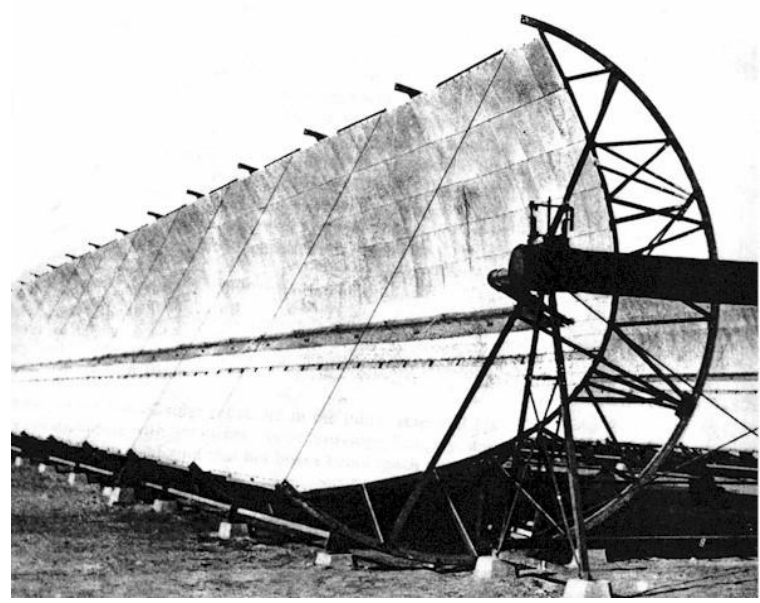

مر آة طولية ذات قطع مكافئ (هلالي) لتركيز الإشعاع أول تفعيل عملي

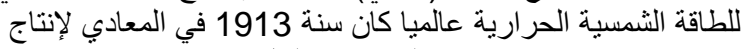
بخار لضخ ماء النيل

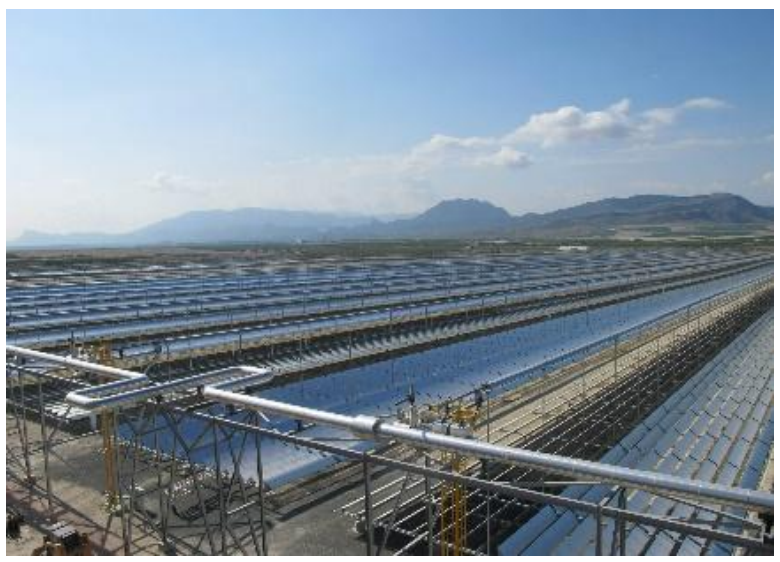

تقنية فرينل بالمرايا المستوية

بويرنو إر ادو في إسبانيا نخزين 0.5 ساعة 